\title{
Research on Finance Mangement for Undergraduates and its Education and Guiding Strategy
}

\author{
Yanrong Ouyang \\ Huanghe Science and Technology College \\ Zhengzhou, China
}

\begin{abstract}
Finance management is a dynamic development and changing process running through the whole life of a person. So a good finance management habit decides his life quality. The college times is the golden times of a person, however, because they didn't receive finance management from family, university or society when they are in college, their ability dealing with money is very poor. Therefore, during college life, educating students with finance management via kinds of methods means a lot for they start their life in society. By researching finance managements conditions of college students, the author concludes their finance management status quo and puts up with some education and guiding strategies to improve their finance quotient in this paper.
\end{abstract}

Keywords-finance management of college students; problems; guiding strategy

\section{INTRODUCTION}

Present college students are mainly the generation after 1990s; their consuming behavior has the characteristics of pursuing individuality, loving entertainment, willing to accept new things and showing self-enhancement. Their values on value, consumption and finance management are greatly different from elder generation. At present, many scholars at home and aboard have researched this problem from the views of their majors, though different majors are they, they get the same conclusion that education on finance management to students during college life plays an important role in their society life. In this paper, the author researches finance management problem by giving out questionnaires to college students randomly and compares the results to get finance management status quo and existing problems, finally put up with education and guiding strategies for improving college students' finance quotient.

\section{Generality on Present Conditions of College STUDENTS FinANCE MANAGEMENT}

In western developed countries, people educate their children finance management conception from a very young age, they help children cultivate proper conception about money and treasure and add finance management education to schooling educational system. Peter Lynch analyzed that the reason why there emerged a great many world-class financiers, entrepreneurs and finance investors in America like John Pierpont Morgan, Lee Iacocca, Bill Gates, Warren
Buffett and himself is that American permeate and heritage their tradition of education and independent cultural well. Influenced by modern history, Chinese research on finance management is very late, until the reform and opening up, Chinese people begun to research on this issue step by step, which is spread accompanied with the rise of insurance and security. While, concerning research on finance management of college students, Chinese scholars begins to research on this problem after 2000. Seeing from the current situations of research on theories, the research on finance management of college students are mainly from three respects: first, the discussion on the education on finance management of college students; second, research on current situations of finance management of college students; third, research on the abuse of finance management tools of college students.

\section{RESEARCH AND ANALYSIS ON FINANCE MANAGEMENT OF COLLEGE STUDENTS}

This research was made by giving out questionnaires to 1000 college students randomly, 951 effective questionnaires were taken back, which accounts $95.1 \%$ of the total. So this research results is effective. Though random research is adopted, according to statistics, it covers majors of economy and finance, literature and arts and science and engineering, and the proportion of boys and girls close to 1 . All in all, result of this questionnaire can reflect finance management situations of college students in general. Introduction to this research and its result is as follows:

\section{A. Contents of the Questionnaire}

The contents of questionnaire involved in informants' basic information, cognition to finance management, source and constitution of present living consumption, daily finance management habit(like keeping accounts or not), what investing tools he knows and whether he has any real or virtual investment behavior.

\section{B. Analysis to Questionnaire}

By collecting the information of effective questionnaires, the author gets the following results:

First, living expenses of college students are increased and the sources are various. With the improvement of living conditions, living expenses of college students each month are increased in a large amount. The majority of college 
students costs 700 1000yuan per month, accounting 36.8\%, students costing 1000 1500yuan account $20.08 \%$, and those cost more than 1500yuan cover $6.83 \%$. while, $83.28 \%$ students' living expenses comes from parents totally, $21.66 \%$ students have chance to get scholarship, and $29.33 \%$ students get part living expenses by part-time work and part-time study. The minority is students getting living expenses by investing finance management products like stocks and funds, accounting $1.58 \%$. These data generally reflect that the sources of living expenses of college students are various. Many students have experiences of part-time jobs, minor students are independent to some extent, they don't ask for money from their parents.

The expenditure of living expenses of college students is for kinds of things. Students spend most of their money on eating and then on shopping. Above 30\% students attend party, travel outside and buy books, school supplies and daily goods. $11.15 \%$ students spend living expenses on love affairs. From the expenditure we know that students' college life is rich because their kinds of expenses and the needs of social contact and love affairs.

The ways college students getting finance management knowledge are diverse. Among the informants, $46.16 \%$ students get finance management knowledge by the popularization of media and banks, which is the most common way. Second, $35.54 \%$ students get knowledge by explanations of friends or reading books. Third, $24.61 \%$ students by seminars of school, but $29.02 \%$ students are interested in finance management without ways to learn it. However, there are $16.09 \%$ students having no interest in finance management.

Primary target of finance management of college students. $55.84 \%$ informants regard spending money properly as the primary goal of finance management. $32.18 \%$ informants think it should be cultivating financial quotient, while $6 \%$ informants choose profit or others.

Sources and ways of finance management of college students. $41.61 \%$ students use the rest of living expenses to invest finance management, $35.23 \%$ students are sponsored by parents, which is mainly concentrated on students majoring economy and finance. $34.81 \%$ students invest finance management by their savings, $28.92 \%$ students use their part-time income during college life as investment, there are also $5.99 \%$ students investing finance management by student loan but $21.77 \%$ students have no money to invest finance management. In terms of finance management ways, $75.18 \%$ informants manage their money by depositing to bank, which far surpass other ways. $11.88 \%$ informants take stocks and funds as finance management methods.

\section{ISSUE of Finance Management of COLlEgE STUDENTS}

\section{A. Students' Cognition to Finance Management Is Partial Even Fault}

During researching process, students are unfamiliar to finance management. Many students think that they have no job or stable income, so it is unreal to manage finance. In other words, they think finance management is for wealthy people, it has nothing to do with them. Such thought is fault. Quite a few students regard finance management as buying stocks, bonds or insurance such things seeming on a high level. This kind of thought is partial. To be honest, finance management is a thing running though the whole life of a person. For college students, daily records of expenditure, planning on living expenses and paying attention to increasing income and reducing expenditure are also included in finance management. Cultivating a good habit and consciousness on finance management and establishing a morality of consumption are significant for college students who are going to society.

\section{B. Consuming Habits of College Students Need to Be Improved}

In college campus, many students often compare to higher or follow the trend when consuming because of face, moreover, some students even change cell phone frequently, eat in upscale restaurants without regarding their consuming ability. Some students developed the thoughts of moneyworship and hedonism, and there are also students who lack of consuming morality and discipline concept. These phenomena show that college students have no mature consuming psychology or reasonable consuming behaviors. Besides, the author finds from the research that $19.87 \%$ students never have plan on living expenses, $45.53 \%$ students plan occasionally, $47.95 \%$ students don't record daily expenditure or budget, and $39.64 \%$ students have the habit to record or budget living expenses but don't carry out strictly. Therefore, many students are rich at beginning of semester but living on loan at the end.

\section{College Students Are Lack of Finance Management Knowledge Generally}

As abovementioned, cognition of college students to finance management is partial or fault, and students have much theory knowledge such as market economic system, market working regular patterns and currency circulation while have little practical knowledge such as financing affairs and investment practices. This is caused by lacking of finance management knowledge of students. It is caused by family, university and society together. Students are brought up by parents without concerning basic necessities of life from the childhood, some students just know that their parents are on duty, but they don' t clearly know what their parents do or the income of family, they only realized that what they should do is just study. However, the school education, which takes up a large amount of time of adolescence, seldom involved in finance management education. When in college, except students majoring in economy or finance, the others rarely learn finance management. While in society, they learn finance management mainly by advertisement. 


\section{EDUCATION AND GUIDING STRATEGY OF FINANCE MANAGEMENT TO IMPROVE FINANCE QUOTIENT OF COLLEGE STUDENTS}

Finance management is a dynamic development and changing process running through the whole life of a person. So a good finance management habit decides his life quality. College times is transition phase of college students from juvenile to social people, is also the golden stage of life. Because of the lack of finance management education from family, school and society, college students have higher IQ and lower "FQ". So, when in college, educating students with finance management by kinds of means, making students without income have correct and comprehensive cognition about finance management and cultivating their positive consciousness to manage money have an important meaning in family finance management when entering society.

Yao Jianjian, Vice-president of Shanghai Jiaotong University College of Humanities, points out that the education on finance management to juvenile should include 3 respects: education on finance management value, teaching basic finance management knowledge and training basic finance management skills. The finance management education of college students should follow the principle that based on the campus, geared to the needs of society and students in the future. Carrying out works from both theory and practice with the combination of characteristics of physiological and mental development of college students.

\section{A. To Carry out the Entrance Education on College Students' Financial Management Project Report}

Now many colleges and universities generally have a one-month freshmen education, which includes military training, military theory, school situation and school history, major presentation, innovation and entrepreneurship education, etc., while it doesn't include financial education. Financial education has always been ignored by family, school and society, however, "financial quotient" is also an important part of quality education. Therefore, during the nascent school education, school can invite financial professionals or financial professional teachers to conduct special report financial seminars in the form of financial project report. Conducting financial education from the beginning of college life can achieve good results, laying a good foundation for finance management learning in the coming four years and cultivation of financial quotient training.

\section{B. To Open Finance Management Elective Course}

Elective course is an important way to broaden students' scope of knowledge. Students from every major can choose this course. The school can open finance management courses that contains both theory and practice in elective courses, such as common sense of finance, family financial management, financial planning, consumption economics, financial management, consumption ethics, etc. By learning these courses, making students understand the financial management, knowing the importance of financial management to life, knowing "financial quotient", forming a correct concept of financial management, mastering certain financial management skills, improving students' understanding of personal finance and consumer ethical theory, lay a good foundation for college life and further development in future.

\section{To Conduct Regular Financial Education Seminar}

School can irregularly invite financial experts and social entrepreneurial elites to hold financial education seminar. They will bring students some financial theory, financial management methods and the latest applications of financial management of society, so that the students can come into contact with the society on the latest knowledge and its application in financial investment. In addition, financial experts and social entrepreneurial elites themselves can bring students a good demonstration effect and motivate students work hard, which can't be brought by the teacher on campus.

\section{To Organize Rich Extracurricular Financial Education}

College students often organize various extracurricular activities, so we can lead students to hold activities in the subject of finance or consumption morality in their organizations, which can be held in the form of debate competition, financial theme exhibition and survival test and so on to form a good atmosphere that advocating scientific finance management, resist bad consumption. By conducting a wealth of financial management education activities to enrich the campus culture, and get very effective financial education effect.

\section{E. To Pay Attention to the Practices of the College Students Financial Activities}

Though learning financial theory and financial management skills are important, it eventually enables students to implement the practice of life. Otherwise it is only an armchair strategist. Therefore, to guide students from making plan of living expenses and spending money reasonably every month to develop good consumption habits and to take part in work-study activities and social practice actively to learn the skills of increasing income and reducing expenditure. If permitted, they can try to use finance management tools such as $\mathrm{Yu}$ Ebao. By finance management practice, college students can improve their skills combining theory with practice, increase their finance quotient and form scientific finance management conception.

\section{REFERENCES}

[1] Hua Tingting. Investigation and Analysis on Students' Financial Man agement[J] - Administrative Assets and Finance 2011 (4).

[2] Du Hanrui, Zhu Xu, Huang Wei, Lu Yuyu. Study on Current Financia 1 Management of Henan College Students and Its Educational Counte rmeasures [J] -Modern Business 2011 (9).

[3] Lv Mengyu. Current Situation of Students' Consumption and Some Suggestions on Financial Management [J] -Market Conditions 2011 (29). 